\title{
EVALUATING FOREST FARMING
}

\author{
I. P. M. McQueen*, R. L. KNowlest and M. F. Hawke*
}

\section{INTRODUCTJON}

ALMost all the discussions on forest farming to date have centred on the tree establishment stage, or at least the very early years of the stand. This being so new a concept, and with few forests planted on farmed grassland, such emphasis is understandable. However, although tree establishment is an important phase, in the end the system must stand or fall agriculturally by the pastoral production obtained among stands for older, say, 4 years plus, trees. The trees will then be beyond browsing damage and the underlying pastures could supply substantial grazing until canopy closure. How much grazing and for how long are major questions to be answered.

Further confusion has arisen over interpretations of what is meant by forest farming. To the forester it may be a question of growing pasture under trees as an alternative source of intermediate income to production thinning for posts or pulpwood. It has other attractions for foresters, such as greatly improved access for pruning and thinning, and reduced fire risk. The farmer, on the other hand, regards forest farming as the growing of tree crops on pasture land for a long-term investment with the minimum of prejudice to current farm production. Each outlook implies a major and a minor interest, and there can be little doubt as to which would be sacrificed in a crisis. A better definition might be "an integrated association of trees and pastures where the combined production provides a greater average net profit than does either forest or pasture alone". Forest farming can be seen as a complete production system, perhaps comparable with grain and fat lamb farming systems, rather than as an opportunist enterprise. Accordingly, in research as in practice, it is necessary to place equal emphasis on both the agricultural and the forestry aspects.

*Ministry of Agriculture and Fisheries, Rotorua.

$\dagger$ Forest Research Institute, Rotorua. 


\section{WOODLOTS, SHELTERBELTS AND FOREST FARMING}

All these can be regarded as methods of tree crop production on the farm. However, they differ markedly in form, intention, and extent.

Woodlots are usually small, perhaps two or three hectares, closely planted, and are intended for aesthetic as well as productive use.

Shelterbelts may also contain crop trees but, in fulfilling their sheltering function, are often inadequately pruned for good quality timber production.

Forest farming involves the use of pasture land with widely spaced trees which must be kept pruned boih to allow optimum pasture growth and to ensure good timber quality.

\section{ESSENTIAL COMPONENTS OF FOREST FARMING}

To have reasonable prospects of success there have to be certain basic conditions present:

(1) High value tree production-this means high quality timber obtainable from well pruned radiata pine or from other marketable species.

(2) Adequate light penetration for pasture growth.

(3) Good access on the farm for timber extraction, and also off the farm to port or market.

(4) Sufficient stock-carrying capacity within the farm so that income is not unduly restricted by the reduced grazing area available during tree establishment and after canopy closure.

(5) Availability of skills for tending both animals and trees.

(6) Adequate stock control through fencing and water reticulation.

\section{BALANCE OF ANIMAL AND TREE PRODUCTION}

The levels of production of livestock and trees which may be considered adequate will depend on the viewpoint of the operator and especially on his need for immediate income as opposed to long-term returns. It is reasonable to suppose that the greater the number of trees the less will be the pasture production. The relationship of numbers of trees per hectare and timber yields is moderately well defined, with Fenton (1972) indicating an upper limit to increases in sawn timber yield lying between 200 and 400 stems/ha. 
Neither pasture nor animal production has been measured among trees at any specific density under controlled grazing management. Overseas studies, reviewed by Adams (1975), refer to extensive grazing at very low animal stocking rates. Observations in New Zealand indicate that good quality pasture can grow right up to the stems of mature radiata pine and other tree species if sufficient light reaches the ground, but that pasture deteriorates in quantity and quality where the light is intercepted by the crown canopy. The extent of the crown canopy cover depends on density of trees, height of trees, and degree of pruning.

The crucial question in forest farming is: "At what level of tree stocking rate can we achieve optimum animal and timber production with relation to ultimate net profit?"

\section{RESEARCH}

Having failed to find a suitable area within established forests, a combined Ministry of Agriculture and Fisheries/Forest Research Institute team decided to start an evaluation with a new planting on established pasture. In 1973 the Tikitere Forest Farming Research Area, $18 \mathrm{~km}$ north-east of Rotorua, was established and planted with various densities of radiata pine. The intention is to study the effects of tree stocking rate on pasture and animal performance.

The six basic treatments are: Control (pasture alone), and radiata pine at 50, 100, 200, 400, stems/ha final crop, and also at 100 stems/ha final crop planted in shelterbelt fashion in twin rows. The plots are 2 ha in size and are each subdivided into two stock-grazing pressures. Treatments are replicated four times, each replicate being on different topography ranging from flat to steep. In order to obtain the final crop stocking-rate, the trees were planted at five times the desired rate and will be subjected to proportional culling. The proposed silvicultural regime (Table 1) is intensive by normal forestry standards but may approximate that required in forest farming.

The measurements sought from the trial include:

(1) Tree height, basal area, crown area, and wood volume.

(2) Pasture production, seasonal rate of growth, and changes in botanical composition.

(3) Animal liveweight gain and wool production.

As trees exert an influence over a substantial area around themselves, a transition or buffer zone has been left around each plot 
PROCEEDINGS N.Z. GRASSLAND ASSOCIATION

TABLE 1: THINNING AND PRUNING SCHEDULE

\begin{tabular}{ccccc}
\hline $\begin{array}{c}\text { Tree } \\
\text { Height } \\
(m)\end{array}$ & $\begin{array}{c}\text { Approximate } \\
\text { Age }(y r)\end{array}$ & $\begin{array}{c}\text { \% Initial } \\
\text { Planting } \\
\text { Thinned }\end{array}$ & $\begin{array}{c}\text { \% Initial } \\
\text { Planting } \\
\text { Pruned }\end{array}$ & $\begin{array}{c}\text { Pruning } \\
\text { Height } \\
(\mathrm{m})\end{array}$ \\
\hline 3 & 3 & 50 & 50 & $!$ \\
5 & 4 & 10 & 40 & 2 \\
8.5, & 5.5 & $\mathbf{1 0}$ & 30 & 4 \\
11 & 7 & $\mathbf{1 0}$ & $20^{\prime}$ & 6.5 \\
14 & 9 & - & $20^{*}$ & 11 \\
17 & $\mathbf{1 1}$ & $\mathbf{-}$ & $20^{\prime \prime}$ & \\
\hline
\end{tabular}

*Final crop.

consisting of a $28 \mathrm{~m}$ strip that is planted at a similar density to the plot concerned. In effect, this creates a space of at least $56 \mathrm{~m}$ between plots, that is, about $50 \%$ of the total area of 93 ha is not directly involved in the trial. Even so, the adequacy of the $28 \mathrm{~m}$ buffer zone may be questionable when the trees approach full height. The buffer zones will be used for access races, for subsidiary trials related to forest farming, and for holding spare animals.

While the main purpose of the Tikitere Forest Farming Research Area is to measure the effect of increasing tree populations on net pasture and animal production, it is obvious that many component effects will contribute to the overall result. It is hoped to study some of these components in more detail at Tikitere. Trials have already started to examine the effect of trees on the growth of different pasture species. Soil nematode populations are being monitored. Studies of changes in microclimate, soil moisture, animal nematode populations, and facial eczema incidence are being planned.

At January 1975 , the trees were 2.5 to $3 \mathrm{~m}$ in height and the first thinning and pruning was being carried out. Growth was a little ahead of expectations. Pasture measurements have started and stock measurements will begin as soon as pastures are standardised following the overspelling inherent in the tree establishment phase.

Meanwhile at Waratah-near Putaruru-a much simpler trial, where trees at 200 stems/ha are being compared with open pasture, has been started among eight-year-old radiata pine. This trial will be used to obtain some preliminary information on the effects of trees on pasture production, to test techniques of measurement suitable for use at Tikitere and to give "early warning" of any problems that may occur in what is a novel system of farming to research workers and farmers alike. 